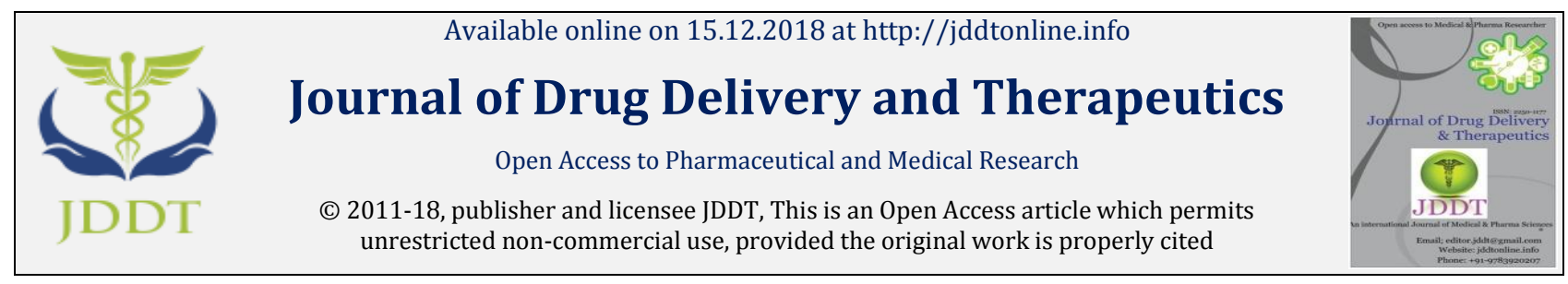

Open $\odot$ Access

Research Article

\title{
Effect of Cynodon dactylon on the haematological parameters and haematocrit of grass carp Ctenopharyngodon idella (Val.)
}

\section{S. Sangeetha, Dr. K. Rajendran}

P.G. and Research Department of Zoology and Biotechnology, A.V.V.M. Sri Pushpam College (Autonomous), Poondi-613 503, Thanjavur district., Tamil Nadu, India

\begin{abstract}
The present study is aimed to investigate the effect of Cynodon dactylon on the haematological parameters of freshwater fish Ctenopharyngodon idella. The study reveals that there was a slight variation noticed in total serum protein, globulin, albumin, glucose, cholesterol and triglycerides. There was a significant variation observed in Red blood corpuscles (RBC), White blood corpuscles (WBC), Haemoglobin (Hb), MCH, MCHC, PCV in the blood of grass carp fed with control and Cynodon dactylon mixed diet. The protein content of experimental fishes showed higher value than other components. The result of the study indicates that the fish are rich source of animal protein and moderate amount of cholesterol and triglycerides. Hence, it suggested that the fish consumed medicinal plants are suitable for human consumption.
\end{abstract}

Keywords: Grass carp, Cynodon dactylon, Haematology, Haematocrit.

Article Info: Received 22 Oct 2018; Review Completed 03 Dec 2018; $\quad$ Accepted 05 Dec 2018; Available online 15 Dec 2018

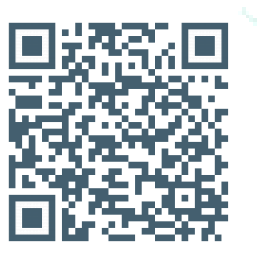

Cite this article as:

Sangeetha S, Rajendran K, Effect of Cynodon dactylon on the haematological parameters and haematocrit of grass carp Ctenopharyngodon idella (Val.), Journal of Drug Delivery and Therapeutics. 2018; 8(6-s):192-194 DOI: http://dx.doi.org/10.22270/jddt.v8i6-s.2111

*Address for Correspondence:

Dr. K. Rajendran, P.G. and Research Department of Zoology and Biotechnology, A.V.V.M. Sri Pushpam College (Autonomous), Poondi-613 503, Thanjavur district., Tamil Nadu, India

\section{INTRODUCTION}

Aquaculture is the farming of economically important aquatic organisms under controlled condition. Development of aquaculture is mainly dependent on availability of suitable nutrients formulated diets. Adding of medicinal plants as one of the ingredient in fish feed improve the immunity of fish and inhibit the microbial pathogens. The study of haematology in fishes used for early diagnosis of disease $1,10,11,12$.

Cynodon dactylon is an important medicinal plant and play a major role in Ayurvedic medicine. It purifying blood, anuria, biliousness, conjuctivities, diarrhea, gonorrhea, itches and stomach ache 16 . According to 13 a medicinal plant Cynodon dactylon act as an antibacterial agent against several bacterial pathogens in the freshwater carp Catla catla. The study on haematology in fishes act as a good parameter, which provides early diagnosis of disease, toxicology, the effect of environmental stress and nutritive value of diets and status of fish health 18,19,20,24,27.

The quality and quantity of dietary protein may reflected biochemical composition, haematology, haematocrit and enzyme activity in fishes 7,18 . The use of alternative feed stuff from plant parts and biproducts should improve growth, nutritive value and immunity of fish 4,15,21. Fish feed containing $C$. datylon influence the growth, biochemical composition, haematology, enzyme activities of fish ${ }^{3,14}$. Blood parameter in fish is easily affected by water temperature, feed intake, movement and photoperiod 2,15,17,22,26. The present study is aimed to investigate the haematology and haematocrite of freshwater carp C. idella fed $C$. dactylon mixed diet.

\section{MATERIALS AND METHODS}

Alive freshwater grass carp Ctenopharyngodon idella fingerlings weight ranging from 50 to $55 \mathrm{~g}$ were collected from Himalayan Fish Farm located at Thittai near Thanjavur. The collected fishes brought to the laboratory in polythene bags filled half with water. This fishes acclimatized for seven days in fibre aquarium. The fish tanks were kept free from fungal infection by washing with potassium permanganate solution, then fishes were disinfected with $0.1 \%$ potassium permanganate solution. The fishes were divided into two groups one as control and other as the experimental groups. Each group consisting of 20 fishes. The fishes were exposed to control diet, and plant powder mixed diet for a period of 30 days. On $15^{\text {th }}$ and $30^{\text {th }}$ day blood samples were collected from both control and experimental group. Blood samples were drawn by cardiac puncture using twenty one gauge hypodermic needle in collection bottle containing disodium 
salt of EDTA. Standard haematological procedure described by Blaxhall and Diasley (1973) were adopted. The methods employed for determination of various haematological parameters were referred to total serum protein (Welchselbaum, 1946), globulin, albumin (Wets, 1965), glucose (Smith, 1979), cholesterol (Fleg, 1973), Triglycerides (Fossatip, 1982) and blood parameters such as haemoglobin (Hb), Red Blood cells (RBC), White blood cells (WBC), Packed cell volume (PCV), Mean Corpuscular haemogloin (MCH), Mean Corpuscular haemoglobin concentration (MCHC) (Daecie and Lewis, 1984).

\section{Preparation of fish feed}

For the present study two types of feed pellets were prepared by following the method of Bindo and Sobha (2004). The control feed was prepared by using standard basic diet ingredients such as rice bran $(40 \%)$, groundnut oil cake (30\%), Fish meal (15\%), wheat flour (7\%), Tapioca flour (7\%), Vitamin and minerals mix (1\%). The experimental diet containing Rice bran (35\%), Groundnut oil cake $(25 \%)$, fish meal (15\%), wheat flour (7\%), Tapioca flour $(7 \%)$, vitamin and mineral mix (1\%) and powder of Cynodon dactylon plant (10\%).

\section{RESULT}

Result obtained for haematocrit values of freshwater grass carp Ctenopharyngodon idella exposed to control diet and Cynodon dactylon powder mixed diet are given in the table 1. From the data, it clearly shows that the haematocrit parameters significantly fluctuated between blood pictures of control and experimental fishes. The serum protein content was found to be recorded maximum in the blood of control and experimental fishes. The biochemical components such as protein, globulin and glucose showed higher value in experimental fishes and it was lower in control fish. Albumin, cholesterol and triglycerides in control fish slightly higher than experimental fishes. The result of the haematological studies of Ctenopharyngodon idella is given in the table 2 . The data clearly indicates that there was a significance increase in the Haemoglobin ( $\mathrm{Hb})$, Red blood corpuscles (RBC), Packed cell volume (PCV), Mean Corpuscular haemoglobin (MCH), Mean corpuscular haemoglobin concentration (MCHC) whereas the White blood corpuscles (WBC) shows slight fluctuation between control and experimental fishes.

Table 1: Haematocrit value of grass carp Ctenopharyngodon idella fed with control and experimental diet

\begin{tabular}{|c|c|c|c|c|c|c|}
\hline \multirow{2}{*}{ S. No. } & \multirow{2}{*}{ Blood parameter } & \multirow{2}{*}{ Initial } & \multicolumn{2}{|c|}{$15^{\text {th }}$ day } & \multicolumn{2}{|c|}{$30^{\text {th }}$ day } \\
\hline & & & Control & Experimental diet & Control & Experimental diet \\
\hline 1. & Total serum protein $(\mathrm{g} / \mathrm{dl})$ & $3.48 \pm 0.26$ & $3.52 \pm 0.28$ & $3.67 \pm 0.25$ & $3.89 \pm 0.27$ & $4.08 \pm 0.24$ \\
\hline 2. & Albumin $(\mathrm{g} / \mathrm{dl})$ & $2.78 \pm 0.13$ & $2.64 \pm 0.12$ & $2.17 \pm 1.14$ & $2.52 \pm 0.16$ & $2.65 \pm 0.16$ \\
\hline 3. & Globulin $(\mathrm{g} / \mathrm{dl})$ & $1.99 \pm 0.11$ & $2.24 \pm 0.14$ & $2.31 \pm 0.18$ & $2.43 \pm 0.15$ & $2.55 \pm 0.22$ \\
\hline 4. & Glucose (mg/dl) & $96 \pm 1.28$ & $99 \pm 1.37$ & $101 \pm 1.48$ & $108 \pm 1.46$ & $112 \pm 1.54$ \\
\hline 5. & Cholesterol (mg/dl) & $141 \pm 1.78$ & $149 \pm 1.67$ & $145 \pm 1.72$ & $169 \pm 1.98$ & $161 \pm 1.86$ \\
\hline 6. & Triglycerides (mg/dl) & $135 \pm 1.57$ & $144 \pm 1.76$ & $140 \pm 1.67$ & $152 \pm 1.81$ & $150 \pm 1.98$ \\
\hline
\end{tabular}

Table 2: Haematological value of grass carp fed with control and experimental diet

\begin{tabular}{|c|c|c|c|c|c|c|}
\hline \multirow[b]{2}{*}{$\begin{array}{c}\text { S. } \\
\text { No. }\end{array}$} & \multirow[b]{2}{*}{ Blood parameter } & \multirow[b]{2}{*}{ Initial } & \multicolumn{2}{|c|}{$15^{\text {th }}$ day } & \multicolumn{2}{|c|}{$30^{\text {th }}$ day } \\
\hline & & & Control & $\begin{array}{c}\text { Experimental } \\
\text { diet }\end{array}$ & Control & $\begin{array}{c}\text { Experimental } \\
\text { diet }\end{array}$ \\
\hline 1. & Haemoglobin (Hb) (g/dl) & $8.59 \pm 0.62$ & $8.78 \pm 0.58$ & $8.97 \pm 0.61$ & $9.47 \pm 0.53$ & $9.89 \pm .71$ \\
\hline 2. & Red blood cells (RBC) $\left(10^{6} / \mathrm{ml}\right)$ & $2.98 \pm 0.44$ & $3.15 \pm 0.39$ & $3.47 \pm 0.51$ & $3.31 \pm 0.45$ & $3.67 \pm 0.55$ \\
\hline 3. & White blood cells (WBC) $\left(10^{3} / \mathrm{ml}\right)$ & $4.70 \pm 0.49$ & $4.74 \pm 0.51$ & $4.77 \pm 0.57$ & $4.76 \pm 0.48$ & $4.85 \pm 0.56$ \\
\hline 4. & Packed cell volume (PCV) $(\% / \mathrm{dl})$ & $30.62 \pm 0.58$ & $31.79 \pm 0.58$ & $31.94 \pm 0.63$ & $32.45 \pm 0.67$ & $32.94 \pm 0.71$ \\
\hline 5. & $\begin{array}{l}\text { Mean Corpuscular haemoglobin } \\
(\mathrm{MCH})(\mathrm{Pg})\end{array}$ & 28.82 & 27.87 & 25.85 & 28.61 & 26.94 \\
\hline 6. & $\begin{array}{l}\text { Mean corpuscular haemoglobin } \\
\text { concentration(MCHC) }(\% \mathrm{mg} / \mathrm{dl})\end{array}$ & 2.80 & 2.76 & 2.80 & 2.82 & 3.00 \\
\hline
\end{tabular}

\section{DISCUSSION}

Blood acts as an internal transport medium which is responsible for supplying oxygen, water, nutrients, food and hormones, removing carbon-di-oxide and nitrogenous waste. It involves in the maintenance of body temperature and production of antibodies 19. Most of the blood parameters are relatively constant under normal conditions and must also have the ability to change it under extreme conditions like stress, food availability, nutritive value of diet etc. $2,17,22,26$.

In the present study haematocrit of freshwater grass carp Ctenopharyngodon idella exposed to Cyanodon dactyon powder mixed diet shows a significant result. The protein showed higher value when compared to other parameters. The maximum value of protein in both control and experimental fishes are agreement with earlier observation 1,10,12,20. According to 16 increase in serum protein, albumin, and globulin in fishes in supposed to be associated with stronger innate immune response. Glucose content in the experimental fish was slightly higher than control fish. However, cholesterol and triglycerides slightly higher in control fish than experimental fish. Similar trends were reported for glucose, cholesterol and triglycerides $13,18,20,21,24$

The haematological parameters such as Haemoglobin, RBC, WBC, PCV, MCH and MCHC showed significant variation, when the fish exposed to Cynodon dactylon mixed diet. The trend of haematological parameters in Ctenopharyngodon idella agrees with earlier observation 1 . Increase level of RBC and haemoglobin were observed in A. hydrophila infected Cyprinus carpio ${ }^{11}$. Juvenile hybrid tilapia fed with high protein diet decreased RBC and WBC level 27. 13 have reported that $\mathrm{RBC}, \mathrm{WBC}$ count increased in 0.5 and $5 \%$ concentration of Cynodon dactylon mixed diet. The RBC, 
haemoglobin, PCV were decreased whereas WBC and lymphocytes were increased when the fish Clarias gariepinus exposed to Moringa oleifera mixed diet 7. WBC, $\mathrm{RBC}$ counts $\mathrm{Hb}, \mathrm{Ht}, \mathrm{MCH}$ and MCHC were significantly increased in the Oreochromis mossambicus exposed to Cynodon dactylon mixed diet 3 .

Biochemical and haematological variation observed in Clarias gariepinus and Clarias batrachus fed plant and plant biproducts mixed diet 4,7,18. According to 14 leaf extract of Cyanodon dactylon to screen the antibacterial activity against infectious disease causing bacterial pathogens. Digestibility, growth, blood chemistry and enzyme activity of Oreochromis niloticus significantly varied when the fish fed with animal and plant dietary byproducts ${ }^{15}$. The result

\section{REFERENCES}

1. Anbalagan T., Rajendran K., Samykkannu K., Soundarapandian P., Veerappan N., The studies on haematological parameters and enzymes of wild and farmed fish Labeo rohita (Ham.). J. Aquatic. Biol., 2008; 23(2):96-100.

2. Anyanwu D.C., Udedibie A.B.I., Osuigwe D.I., and Ogwo V.O., Haematological responses of hybrid of Heterobranchus bidorsalis and Clarias gariepinus fed dietary levels of Carica papaya leaf meal. World Rural Observ., 2011; 3:9-12.

3. Aruldoss K., Kanna R., Chandira A., Sankar Samipillai S., Effect of Cynodon dactylon on the haematological parameters in the blood of Oreochromis mossambicus. Int. J. Modn. Revs., 2014; 2(5):171-177.

4. Bellow O.S., Olaifa F.E., Emikpe B.O., Haematological and blood biochemical changes in Arican catfish, Clarias gariepiinus fed walnut (Tetracarpidium conophorum Mull Arg.) leaf and onion (Allium cepa Linn.) bulb supplemented diets. American J. Experiment. Agricult., 2014; 4(12):1593-1603.

5. Blaxhall P.C., Daisley K.W., Routine haematologic methods for use with fish blood. J. Fish. Biol., 1973; 5:771-782.

6. Dacie J.V., Lewis S.M., Practical Haematology (ed.). Churchill Livingson (ed.). Selecto Printing Co. Ltd., New York, 1984, pp.445.

7. Dienye H.E., Olumuji O.K., Growth performance and haematological responses of African mud fish Clarias gariepinus fed dietary levels of Moringa oleifera leaf meal. Met. J. Agricult. Sci., 2014; 2(2):79-88.

8. Fleg H.M., Ann. Clin. Biochem., 1973; 10:1350-1356.

9. Fossatip Lorenzo, P., Serum triglycerides determined colorimetrically with an enzyme that produces hydrogen peroxide. Clin. Chem., 1982; 28:2077-2080.

10. Gabriel V.V., Ezeri G.N.O., Opabunmi O.O., Influence of sex source health status and acclimation on haematological of Clarias gariepinus (Burch). African Journal of Biotechnology, 2004; 3:463.

11. Harikrishnan R., Nisha Rani M., Balasundaram C., Haematological and biochemical parameters in common carp Cyprinus carpio following herbal treatment for Aeromonas hydrophila infection. Aquacult., 2003; 221(1-4):41-50.

12. Hickely C.R. Jr., Comparative haematology of wild and captive cunners. Trans. Am. Fish Soc., 1983; 111:242-249.

13. Kaleeswaran B., Ilavenil S., Ravikuma RS., Changes in biochemical, histological and specific immune parameters in Catla catla (Ham.) by Cynodon dactylon. J. King Saud University (Sci.), 2012; 24:139-152.

14. Kartikey Pandey C.S., Singh Raj K., Prasad A.K., Mishra M.K., Studies of antimicrobial activity using leaf extract of Cynodon dactylon. Scholars Research Library. Derpharmacia Letter, 2016; 8(3):325-330. of the study revealed that in C. idella haematological and haematocrit values were within acceptable limits when the fish fed with $C$. datylon mixed diet and control diet.

\section{CONCLUSION}

The study reveals that the experimental fish Ctenopharyngodon idella are hygienic, good nutritive value, rich protein with moderate amount of glucose, cholesterol and triglycerides. Further Cynodon dactylon mixed diet increase the protein and immunity and decrease triglycerides level. Hence, it suggested that the fish fed with medicinal plants mixed diet is suitable for culture and human consumption.

15. Magnolia Montoya Mejia, Manuel Garcia-Ulloa, Alfredo Hernandez-Llamas Hector Molas Co-Soria, Hervey RodriguezGonzalez, Digestibility, growth, blood chemistry and enzyme activity of juvenile Oreochromis niloticus fed isocaloric diets containing animal and plant byproducts. R. Bras. Zootec., Brazilian J. Anim. Sci., 2017; 46(2):873-882.

16. Muthu C., Ayyanar M., Raja N., Ignacimuthu S., Medicinal plants used by traditional healers in Kancheepuram District of Tamilnadu, India. J. Ethnomed., 2006; 2:1-10.

17. Osuigwe D.I., Nwosu C., Ogunji J.O., Preliminary observations on some haematological parameters of juvenile Heterobranchus longifilis fed different dietary levels of raw and boiled jackbean seed meal. Proceedings of Conf. of Inter Agri. Research Development, Tropentag University of Kassel, Witzenhausen and Univ. of Gottingen, 2007; pp.6.

18. Mishra P, Gupta S, Efficacy of stem extract of Eclipta alba on biochemical variables of Clarias batrachus. Indo African J. Pharmaceut. Res., 2014; 4:6.

19. Raizada M.N., Singh C.P., Observations on haematological values of freshwater fish, Cirrhinus mrigala (Ham.). Comp. Physiol. Ecol., 1982; 7(1):34-36.

20. Raizada M.N., Jain K.K., Raizada S., Monthly variation in the haematocrit values (PCV) in a teleost, Cirrhinus mrigala (Ham.). Com. Physiol. Ecol., 1983; 8:190-196.

21.Rao V.Y., Das B.K., Jyotymayee P., and Chakrabarti R., Effect of Achyranthes aspera on the immunity and survival of Labeo rohita infected by Aeromonas hydrophila. Fish and Shellfish Immunol., 2006; 20:263-273.

22. Siwicki A.K., Anderson D.P., and Rumsey G.L., Dietary intake of immunostimulants by rainbow trout affects on specific immunity and protection against furunculosis. Vet. Immunol. Immunopathol., 1994; 41:125-139.

23. Smith M.G., Biochem., 1979; 18:5067.

24. Tandon, R.S., and Joshi, B.D., Studies on the physiology of blood of some freshwater fishes of India. 1. Normal blood glucose and lactic acid levels. J. Inland Fish Soc. India, 1975; 7:1-6.

25. Welselbaum T.E., An accurate and rapid method for the determination of protein in small amount of blood serum and plasma. Am. J. Clin. Path., 1946; 16:40-90.

26. Yang S.X., Xie X.M., Jiang A.Q., and Zheng T.S., A comparative analysis of blood physiology and biochemistry indices between Channa maculate and Ophiocephalus argus. HR Bei Fishery, 2007; 9:21-23.

27. Yue Y.R., Zhou Q.C., Effect of replacing soyabean meal with cotton seed meal on growth, feed utilization and haematological indices for tilapia. Aquacult., 2008; 284:185-189 